\title{
Roundtable Discussion on Homegrown Theorizing
}

\section{$2^{\text {nd }}$ All Azimuth Workshop: Widening the World of IR Theorizing}

\section{3-24 September 2016, Ankara}

Ersel Aydınlı (Bilkent University): Many people may not find the focus of this particular workshop to be relevant to what we study or how we see IR, but we believe that the accumulation of these different efforts might produce something at the end of the day. Our Center is a small one and our journal is primarily dedicated to being a platform for these types of discussions.

I want to raise some preliminary questions to open this roundtable discussion, and I hope we will have an extensive and very engaging discussion.

First of all, "Is there a need for post-Western theory?" It is somewhat off-putting that we still have to ask such existential questions. Moving on from there, "Can there be a postWestern theory?"; "Can IR theory be widened to include global alternative voices?"; "How can local IR communities engage with IR theory?"

Then there are more technical questions, such as, what we are going to do with 'homegrown theorizing'? What are the ways of doing it? Are we going to redefine the concepts? Ask new questions? Or present brand new ontologies? What are the best ways of making homegrown theorizing more appealing to core IR theory? A lot of us pointed out that recognition is an issue. Many of the traditional gatekeepers are finally dying. So what is really stopping homegrown theories from moving into and becoming a respectable part of the core IR theory? And maybe more importantly, before that, what are the best ways of making homegrown theory relevant? Is it the predictive capacity? Or evidence based knowledge? What are the pitfalls for homegrown theorizing? Throughout our panels some of these became very clear, for example, misrepresenting some concepts became an issue in the cases of Islam and Guanxi. In the name of homegrown theorizing are we neglecting what already exists? Are we being thrown into simply an anti-Western approach? This would be extremely problematic, as most useful products would go to waste. In the name of homegrown theorizing, are we making ourselves vulnerable to local governmental use and abuse? Some of us might think this is the case. For example, in Turkey somebody came up with a theory regarded as homegrown and for a while it became the basis for Turkish Foreign Policy (TFP). Many of us now think that it was one of the biggest TFP disasters ever. So is there that risk too? Could homegrown theorizing be divisive? In Turkey when we push for homegrown theory, some of our colleagues say that it is divisive. They argue that we should integrate our forces, we should study what has been studied in the core and contribute that way. Finally there are questions about originality. "What does homegrown theory originality mean really?" And one of the last questions, "How do we overcome negligence by the core IR community?

Are we really exaggerating? Are we seeking something that does not exist? The core followed a route, now we are following it, why?

Before going around the table to ask your thoughts on these questions, I'd like to give you some time to reflect by first asking one of our colleagues to comment in general on what has 
been happening with Turkish IR in recent decades. He has been a pioneer in institutionalizing the IR community in Turkey and publishes an IR journal in Turkish.

Mustafa Aydın (Kadir Has University): The IR community in Turkey is fairly young: it started in the 1980s. We established the first association, Uluslararası İlişkiler Konseyi (International Relations Council) in 2004, and begun to publish the flagship journal of the Council, Uluslararası İlişkiler, in Turkish. The journal's specific mission was to encourage and promote theoretical studies and conceptual works of international relations in Turkey. We actively encouraged our authors to write papers with a theoretical framework, which was the most difficult part of our job because most of the articles submitted were usually topical and descriptive, and were not really engaging in conceptualization. There are still fewer articles with a theoretical framework, but they are usually much better both in quality and style than topical articles.

We also encourage authors to publish in Turkish to fill in the gap in Turkish IR literature. That has also become a challenge because most Turkish scholars, even most of our own authors, do not cite articles written in Turkish while writing in English. This is a huge problem because a journal's reputation depends on its citations. Uluslararası İlişkiler has been included in Thomson Reuters Social Science Citation Index (SSCI) since 2008 and it is the only such International Relations journal published in Turkey. Getting a considerable number of citations is very important to be able to continue being indexed in SSCI. Since Turkish authors do not cite Turkish sources when writing in English, and since there are not any other journals in Turkish in SSCI, increasing citation counts of Uluslararası İlişsiler has been a true challenge.

Apart from the above challenges, there are a couple of reasons for the lack of homegrown theorization in Turkey. The first is the lack of foundation at the pre-university education level. A lack of conceptual thinking is not endemic to IR or to undergraduate studies, but is pervasive in the general education system in Turkey. Turkish high school education does not encourage conceptual thinking, which is a huge problem. When students come to the university level, they are unable to think conceptually and they do not like those professors who conceptualize things. Moreover, the high school curricula do not include classical philosophy. It is very hard to teach theory to university students who have never even heard of the classics. IR theory is based on those classics. I believe that a successful theorist must have already mastered the classics in high school, and opportunities for doing so are lacking in Turkey.

The second problem is related to the maturity of the field. Even though International Relations has been taught in Turkey since the 1950s, the current generation of graduates is almost the first generation to have studied IR theory in Turkey. My own generation, now senior professors, is the first generation in Turkey to study IR as an undergraduate field. This was in the 1980s. Our professors had studied history, political science, or international law, even though they eventually became IR professors. Moreover, our generation did not study IR theory while we were studying IR as undergrads. Someone who did her IR $\mathrm{PhD}$ in the US was saying that in the US they were talking about four theories and nothing else. But when we were studying in Turkey, there was only one theory! I was taught that IR theory means Morgenthau's realism of course. Realism did not exist before Morgenthau and it did not exist after him. Our generation is the first generation who started teaching IR theory as an undergrad course in Turkey. This was in the 1990s. I think the field is not mature yet in that sense. 
There is also a problem with the center-periphery global discussion in terms of theorization. On one side, Turkey is a part of the periphery, because if you send an article from Turkey with a Turkish sounding name to an American journal, it will most likely get refused or not pass the editorial cut. If you have a Turkish sounding name and send an article claiming that you are addressing IR theory, you will get an editorial cut. What we are expected to do is to use these theories developed in the US or the West in general, and try to employ them in analyzing Turkish foreign policy or Turkey's neighborhood. This is being part of the periphery. But at the same time, when we look at the TRIP surveys, they show that Turkish academia is too much integrated with the Western or global IR community. When I say too much, I mean that we are more than anybody else. When we are talking about various issues or various countries, compared with academics from Chile or Hong Kong for example, it seems that Turkish IR academics identify themselves with much more Western academia than anybody else. This identification is not just ideational identification, it is also about the matters we like to study or talk and about the methods we claim to use in research. To have a homegrown theory, you have to have a healthy distance and a healthy dislike of what is happening in the Center, so that you can create an alternative. But if you identify yourself with that theorization and you think yourself as a part of that theorization, you don't have the urge to develop an alternative. That is the two sides of a kind of contradiction in being part of both the center and periphery.

There is also another reason: weak institutionalization. As I said, the association and journal all started in 2004. The problem is not only evident in the association or the journal but in the universities too. How many universities or IR departments can you think of that they are dealing with more than one theory and discussing them in their lectures? Very few. Very few, even in Istanbul and Ankara.

And yet another problem, even if you are a theoretically grounded person, you face the situation that you are not able to discuss your ideas with anybody. IR professors, like in many other disciplines, are very dispersed. We don't congregate enough. Every two years we have an IR congress. But that is not enough.

Ersel Aydınlı: But there is also some type of a theory fetishism. People like the label. The theoretician is also an identity that many young academics would love to present themselves. So there are a lot of theoreticians, self-claimed theoreticians, but we don't see the outcome.

Mustafa Aydın: When I was in Ankara University I started to teach theory. The department used to advertise me as a theoretician, but I was not. I was teaching the theory course, that is what happens. Now, I'll give you a few points from our TRIP research. First of all, the Turkish IR community is a relatively young community if you compare it to the global IR community. Hong Kong is the youngest in the world. But we are by average much younger than other IR communities. When we asked in the survey, "What is your main research area?", we found that research methods in Turkey is zero percent. Nobody has made their main research area as research methods. Political theory and political philosophy get $1 \%$. But if you don't have strong foundations in political theory or philosophy, you cannot build IR theory on it. Regional studies were $25 \%$. When we ask them about their theoretical approaches in their writings, realism is number one (33\%) and constructivism is $28 \%$. This is globally $19 \%$ realism and $23 \%$ constructivism. This is the first time we found out that constructivism has passed realism in the world but not in Turkey yet. I am saying 'yet' because we also asked another question: What was your original theoretical approach when you started studying 
IR and it changed on the way, and $49 \%$ said it was realism. This is down to $33 \%$. So it is dropping, but not at the same speed with the global trends. It is interesting that in Turkey $10 \%$ of scholars say they are not using any theoretical approach in their studies. In the world it is actually $26 \%$. We are going totally different ways. There are people who are refusing to use a theoretical approach. This is something that is not understood in Turkey.

Ersel Aydınlı: Thank you for these thoughts. With all that in mind, I'd like to now go around the table and hear everyone's comments and ideas on the questions raised at the outset.

Emre Baran (Middle East Technical University): I'll start with the $5^{\text {th }}$ question, i.e. what should be the purpose of homegrown theory. I think theory building seems to have a psychological dimension. Looking into the purpose of theory building -whether we need homegrown theory or not- can give insights about this psychological dimension. Some of the key concepts that are mentioned in the workshop, for example self-confidence, respect, humiliation, need for recognition, acquiring another identity, punishment and exposure are embedded within the psychological and emotional condition of the society that the researcher is a part of. As Prof. Mallavarapu said, theory building is to become a subject of one's own thinking, which I understand encompasses mindfulness and reflexivity. Prof. Joergensen also touched upon this relationship by highlighting the critical potential for theorizing. I think we can have further insight about the need for a homegrown theory by reflecting on this psychological dimension. For example, does the researcher want to uphold his or her own culture against a colonial background? Or does the researcher want to contribute to ongoing debates by adding new authentic ideas and concepts? I think exploring these questions may prove insightful to understand the purpose of homegrown theorizing, because the politics behind these motives are very much different.

Andrey Makarychev (University of Tartu): First of all, there are theories that to some extent are homegrown. Take the English school, for example. They are based on certain local traditions and certain scholars that happened to work together for some time. All theories are based on certain kinds of homegrown premises to some extent, therefore it depends on what we mean by discussing homegrown theory. Within the Western academy, we also have traditions beyond the West. I would like to emphasize three challenges that homegrown theories in the non-Western world might face and are already facing. First is the danger of fragmentation. Do we need a kind of theory for each identity, for each nation state? Do we need Estonian IR, Georgian IR etc.? The recent danger of fragmentation in this field, if we go ahead with these, is that we can face a very fragmented professional field. The second challenge is the distinction between what I call academic theories and political doctrines, and sometimes they are very mixed with each other. I think that we need to struggle for purity of academic theories as distinct from political doctrines, because, as we discussed a couple of times, how political elites can hijack or capture academic knowledge or theories and the kind of transformation these academic ideas might face at the end of the day. I would say that in this sense homegrown theorization should be vigilant about the danger of transforming into political statements rather than academic theorizing. Sometimes when I analyze different literatures, some post-colonial theories, I see more political statements than academic theories. That is my personal experience, in non-Western academia. The third danger is the challenge of being repetitive. There are a lot of margins, borderlands, all kind of identities in between which can be well studied based on the Western tradition of critical 
thought. Sometimes, these traditions are even more effective for understanding these noncentral actors. In many respects, more or less well established theories might be used exactly for the same purpose as post-colonial approaches. This is to some extent a challenge of repeating critical voices within the Western theoretical academia.

Karen Smith (University of Cape Town): I wanted to pick up on some points made by both speakers in the previous panel, which was the link between teaching and homegrown theories. It is very important because the question which I often wonder about is "to what extent are we allowing US IR to remain hegemonic in our teaching practices?" even though we sit here and talk about how we encourage homegrown theorizing, I think, including myself, a lot of us, especially in undergrad level, still teach IR in a very specific way which I don't think is conducive to and encouraging theorizing. Here I differ from perhaps one of the points made by Mustafa Aydin that his generation of IR scholars in Turkey was disadvantaged by not having IR at the undergraduate level. I think in fact when we teach IR generally in a very traditional way at the undergraduate level it in fact impedes theory building. Perhaps, I think you should see it as a very positive thing. I try to encourage all of us to not forget about the teaching aspect when we think about how to take this forward. Another point may be just to add to the list of questions "how to take this practically forward?" Some of the things discussed here helped me realize that there are lots of groups now all over the world working together on this issue. I think it would be useful for all those to be somehow combined. For example, Siddarth and I are part of another group, not necessarily part of this group. So I would love to see one big conference of people, all of us working on non-Western or peripheral IR theories. I think we really should make use of the opportunities there. I can think of three books series that are out there urgently looking for books that present non-Western approaches to IR. Perhaps that would be one way or another way which we can disseminate some of the very interesting ideas that came up in this workshop.

Ramazan Gözen (Marmara University): I will focus on why we won't have homegrown, actually non-Western IR theories in IR out of my experience from the Turkish case. May be I will make a big exaggeration, too much of a generalization, but I think this is mostly related to our developing underdeveloped categorization. In the Cold War years, we taught in IR about Western developed countries, southern underdeveloped countries. I think in this kind of categorization there is a truth about homegrown theories. Why would we have homegrown theories or non-Western theories? Why Western theories are hegemonic in IR theories is partly related with this kind of Western-developed and non-Western-underdeveloped issue. Here one of the important points is the freedom of thought, especially in our country. One of the reasons why we don't have, for example, so many different ideas and theories related with social issues concerning IR is mostly related with the ideological hegemony and ideological propagation. And this is partly related with the education system in this country. This is a problem in most of the third world countries: lack of freedom of thought, problems with the education system, the type of state ideology, etc. I think in this kind of environment you don't have philosophical debates. Most of the students do not know how to ask. They are afraid of asking questions. Maybe this is partly related with our country, our family traditions. We don't ask questions. If you are oppressed not to ask different questions, how can you produce theories, different ideas? This is mostly related with the characteristics of this non-Western world. Another point I want to raise is that by trying to make up homegrown theories, we should not isolate ourselves from the mainstream theories, or debates and agendas. For 
example in the Cold War, some Third World formations, initiatives tried to create a different world, cut off from the West, from the Colonial countries, in order to create a new, completely different world. That was difficult, almost impossible to achieve. At the end, I think we should not fall into this trap of making original, completely new non-Western theories, but instead aim for better integrating with the main traditional theories. Asking new questions to the existing theoretical debates would be the best contribution to the existing IR literature, I think.

Mustafa Aydın: Starting with this originality in homegrown theory, especially in countries like Turkey where there is no tradition of contributing to mainstream theorization, it is too ambitious to start talking about originality. Looking at the examples of non-Western theory contributions globally, most of them are using some sort of a local idea turning into a global conceptual explanation. There is a problem for Turkish academia too. We are too cut off from older or ancient ideas of Turkish past to be able to use them. Political Scientists in Turkey have used Ibn Khaldun to modernize it and to talk about it for state theory. Nothing comparable happened in the Turkish IR community. Maybe it could have happened, I have no idea. On the question of homegrown theory, what do we mean by homegrown theory? As Ramazan also pointed out, are we attaching ourselves to traditional or non-traditional theories and enlarging on them or we have so much ambition to develop a theory everybody would just jump in and follow? That is not going to happen. The big question is, there are more Turkish academics living abroad, studying IR then doing the same thing in Turkey. When we attend the ISA conventions, "Turkish" communities are one of the biggest ones. So why those Turkish origin people who are living in the US and studying theory are not contributing to the mainstream theory is also an important question.

Pınar İpek (Bilkent University): Thank you for all the participants and people behind this organization. I have been listening to the entire workshop except for yesterday's afternoon session. I must say that I am annoyed by this dichotomy between post-Western versus Western theorization. I find it quite dangerous, as some of us already mentioned. I personally reject the first two questions, i.e. whether we can build or need a post-Western theory. Then the third and fifth questions...

Ersel Aydınlı: What do you reject? Do you disagree that there is a need or do you reject the label?

Pınar İpek: The division between post-Western and Western. Where is "the West"?

Deniz Kuru (Turkish German University): So you do not think there is a need either.

Pınar Ípek: No, I mean there is no need. Maybe it is about again the philosophy or understanding behind the label that comes in front of the word "theory". I find homegrown more useful because, as my colleagues already mentioned, all theories--traditional or emerging--are to an extent local. My understanding of homegrown is local. As a modest contribution to this workshop, my main focus will be on questions number four and five. Like Emre, I feel like there is more to the motivation for recognition. I have not heard a lot about this in most discussions, except the first session yesterday, where Ersel mentioned that. It seems like everywhere around the world there is a universal search for some theorizing or more and more talking about the limitations of, let's say, orthodox or traditional theories. My point is why the need? What are the conditions behind it? My modest answer is probably, the transformations--however you see it--and the change in the historical patterns. That gives us answers to all where the West is, post-West is, what is ancient, what is philosophical. Rather 
than focusing on more recognition, my suggestion is to focus on the need. Why in certain times, like my colleague also mentioned, the English school emerged. It is not just a market, right? There are historical breakthroughs and some emerging problems that academics try to understand and/or explain. That is my last point. Very quickly, as a self criticism to the periphery--I prefer to use core-periphery--Indeed, our Iranian colleague, Homeira finished her presentation with 'confidence'. To ask the question number eight, the confidence in periphery. Given the self-criticism I brought, and I agree with all the points about the cultural issue Dr. Gözen mentioned and about the general education system, we need trust among scholars in the periphery. Trust among scholars in the periphery, in terms of the quality of the journals, the citation problem and of course professional pressure like we have to produce something.

Ersel Aydınlı: Pinar mentioned that we have to focus on the need, the recognition. You are so right actually. Maybe it has been underemphasized but I have to say it. The reason we organized this workshop is because some of us believe that core IR theory is in crisis. It cannot explain global affairs. It is misleading and it is confusing. In fact, theories are piling up but, as that famous title reminds us, so are the bodies piling up in the Middle East, and here and there we have civil wars and terrorism. But core IR theory is doing the littlest on these issues. That is the reason for our engaging with this. The primary reason to make IR theory richer. So that maybe there would be new explanations for all these problems that core IR theory has been failing to explain adequately. This is why we would like to engage in homegrown theorizing. The name is problematic. I think we should call it more theorizing, or more plurality in theorizing, but it has to include fair access to publication and overall recognition. Just like the labor unions say, we would like to be represented. All the ideas, fair representation. I mentioned earlier the dying off of many gatekeepers, but I don't believe that all gate keepers are disappearing. The gate keeping is institutionalized. Every journal is institutional at the end of the day. To repeat, and this is critical I believe, IR theory is not working, it is not explaining things. What is it explaining in Syria? Did you know, there are no IR theories of informal violence? More people are dying in non-state violence than as a result of state violence. But there are no real theories of it. We need theories to explain what is happening to us, and that is why we are doing this.

Haluk Özdemir (Kırıkkale University): Yesterday I talked about my problem with concepts. And today we are talking about similar issues: homegrown, Western, non-Western. Whatever the label is, we need to focus on what we need to do, what should we do. Are we going to reject all Western methodology concepts, theories, paradigms everything? Sometimes we sound like we want to reject everything Western. If we mean by Western, everything, all the information all the knowledge about IR produced up to now that is called Western, I think we give too much credit to the term West. I think what we call Western already employs some of the non-Western knowledge. I think we call it Core IR, because this Western/non-Western creates some kind of competition. It is like we are coming to get you. We want to have recognition. We want to have original ideas; we want to make a contribution but we are also kind of threatening the Core to destroy the Core. Ersel talked about the shortcomings of Core IR. Our main focus should be contributing to the Core and overcoming those shortcomings. Yesterday I talked about what should we do? Should we try to contribute? Or should we try to be original? Something completely new. If we try to be original, this really raises the expectations. The great expectations lead to great disappointments. Not to be disappointed, 
we should narrow it down and limit our goal to contribution to the Core, because that is the only thing that would give us recognition. We don't want to destroy something that we want to get recognition from.

Deniz Kuru: Generally we have discussed about the word local, but I think yesterday Dr. Mallavarapu pointed out that there is this new school or new approach of local history under the conditions of globalization at the close of the $19^{\text {th }}$ Century. In the $21^{\text {st }}$ Century we are no longer able to pinpoint certain things and say "OK, it is our local things and they are native and original." There are not many ideas or philosophies which are not of a more global character. It is getting more and more difficult to find those things. One major problem which I see is in the future with regard to homegrown theorizing is the threat of falling into the trap of creating some caricaturized versions of different thinkers. That happened with mainstream IR. Everyday there is a new clever and revisionist scholar who writes about all the problems with that kind of explanation about all these past thinkers. If we are doing non-Western theorizing or if we are going to engage ourselves with all these thinkers from the past, from the non-Western world, we should be very careful to make sure that we are not going to create those kinds of caricatures. because you can in the future fall into that trap. One last point is about the issue of emerging schools. I don't think that schools emerged. They are created or established. They are not necessarily started by themselves. For example, the English school was started by an American grant that brought together British scholars, and they wanted them to create a joint theory. Then we speak about the need. The need is what we are taught with it. That is also a market question I think. If we are successful, if we are eager to pursue our different agendas then we can succeed. One really final point, I think the differences around the views in this workshop are that, there are people who are from this logic, point of view or positivist and who are post-positivists. At some points we kind of talk past each other. Not in a negative way, but there are different thoughts.

Chih-yu Shih (National Taiwan University): I think there is a difference between postWestern and non-Western IR. They serve different functions. Post-Western IR tries to transcend the dichotomy between the Western and the non-Western. So it is impossible for anyone to be Western or non-Western. Everybody is post-Western. Non-Western IR just looks for the origin of intellectual sources that can provide lessons and perhaps even rules that governed international relations before the West has arrived in the non-Western world. Both post-Western IR and non Western IR are useful. On the other hand, both post-Western and non-Western IR have the danger of recentralizing the West, because in most post-Western IR agendas they study how the local, i.e. 'the site' has been influenced or constituted by the Western IR and revise them in certain ways. The assumption is that everybody seems to know what the West already said. I think that is the problem of post-Western IR, there is no conscious attempt to treat the West as a combination of post-Western sites. And every Western site is in itself also a post-Western site. In other words, not just the non-Western world be constituted by the Western values and institutional theories, but political sites in the West are also constituted by non-Western resources. There has been a historical continuity in which the west learns from the non-Western world. So making post-Western inspiring an agenda, to understand that post-West and non-West become hybrid, become mutually constitutive. And I think post-Western IR must also study the history of re-Worlding in the West. How the West become Worlding? If we don't do that then we risk centralizing the West. So, we need to modify the West and then study how each different Western site is also at the same time a post-Western site. 
On that note, I would like to make a metaphor for efforts to create homegrown IR theories. I would like to use Chinese chopsticks as a metaphor. We can argue that chopsticks are no longer useful for this world because we can eat any food without chopsticks. We can argue that chopsticks are useful for eating Chinese food, and everyone should use chopsticks to eat Chinese food in order to appreciate or enjoy Chinese food. But they don't need chopsticks for other food. That's the specific function. The third possibility; chopsticks are good for Chinese people to eat any food in the World, but no one else needs to use chopsticks. So chopsticks become useful for a particular population, not for anyone else. Fourthly, chopsticks can be used for anyone who wants to use it to eat any food. So people who don't use or are not used to Chinese food can use chopsticks to eat. Chopsticks can be useful universally but differently for different people. Consider chopsticks as homegrown IR theory, then think about how this particular theory will be accepted outside its home. We can use these four possible metaphors to categorize its use: One, it's not useful for anyone. Two, it is useful for a particular function. Three, it is useful for a particular people. Or four, it is useful for people who are outside the particular whole. They learn something differently from the people of homegrown theory. That is how I see the function of homegrown theory and also the function of post-Western and non-Western IR. It really depends on what we want to do. If we want to transcend the dichotomy of West vs. non-West, then we do post-Western IR. We will not tell our people that you must do Western IR because we want to transcend the dichotomy. Some people believe that there are original intellectual resources in their intellectual history, that have never been included by the Western thought and that can be useful for the contemporary World. That does not mean that they could tell everyone else to do non-Western IR. That is a little different from the way you categorize homegrown theory, because you categorize it from the whole point of view. I define these four categories to categorize homegrown theories in the eyes of those people also.

Siddharth Mallavarapu (South Asian University): At the outset, I would like to congratulate the hosts of the conference for making available this creative space to think about theorizing more generically from the global south and specifically about the Turkish experience. These spaces are indeed few and it is particularly appreciable from that point of view.

To begin with we must acknowledge that the West/North or East/South is not a monolith. Disciplinary histories of IR reveal the strong connections with the fortunes of the major powers (e.g. $19^{\text {th }}$ century Britain, $20^{\text {th }}$ century United States). There is something called the core which often takes on the mantle of producing theory. We must not reject theory merely because of this. We should assume a moderate position which does not require us to throw the baby out with the bathwater. Instead we must demonstrate that theoretical work also takes place in the global south. Theory is far too fundamental a domain of knowledge.

I agree with Prof. Ersel Aydınlı's proposition that it is true that core or mainstream IR theory is unable to answer many of the questions that concern us in our parts of the world. The world must therefore be viewed from distinctive locations. We should acknowledge that theory is produced from different locales. Theoretical work does take place in the global south. The challenge is to identify these strands and bring them into a serious conversation with other existing strands. A special anxiety is attached to theory given its standing within knowledge systems. A fundamental domain of knowledge must encourage diversity. Revisionist historiography reveals clearly that IR is not a neutral discipline. Particular modes 
of socialization, the effacement of colonialism, Eurocentrism (treating European experiences as the universal), the silences of race, gender and class need to be accounted for. Robert Vitalis in his book White World Order, Black Power Politics argues that in 1910, the Journal of Race Development was the first journal of IR. There is something to be said about the partisan nature of knowledge. As Cox suggests, IR is an ideological formation. Like all ideological formations it has its own inclusions and exclusions.

Prof. Mustafa Aydin's point about the distance from the mainstream is an important observation. We need to be patient and do our own thing without being too beholden to mainstream paradigms. We must also be willing to contest mainstream claims. Years ago Albert Hirschman penned a piece titled 'paradigms as a hindrance to understanding'. That has a special ring today in the global south. Paradigms can imprison us.

The challenges of weak institutionalization, the absence of peer review of IR in many parts of the world still remains.

Prof. Karen Smith's emphasis on bringing together various attempts of theorizing from around the world to contribute to IR merits further thought and deliberation.

Our intent is not to score national points or to suggest that we must not engage the West merely because of its location. However, we need to be critical and recognize power relations that underpin knowledge claims. We must participate in a global conversation and enrich it from our own locales of experience and engagement with the world. As Terry Nardin has suggested earlier in one of his writings that 'different traditions pose different questions', the real challenge is to embrace these possibilities.

Ching-Chang Chen (Ryukoku University): Some of the issues I have in mind have been covered so far, I would add a quick footnote to Prof. Shih's comment about academic decisions to practice post-Western IR theorizing or not. Two years ago I co-authored a book chapter with Prof. Shih, and in our chapter we mention that Taiwanese IR academics, most of them, graduated from American Universities. It is interesting that it is quite hard to see anyone who is trying to do homegrown IR theorizing in Taiwan. Most people are not concerned about that. They are not interested. Why? In our chapter, we believe that it has to do with identity function of IR theory. If you are able to practice Western IR, if you can teach Western theory and you apply Western IR theory in your research, then somehow you acquire sort of the image of Americans. And for a post-colonial society like Taiwan, whose national identity is increasingly becoming or trying to make a distinction between Chinese and Taiwanese. This country imagines Americans as a useful reference point to demonstrate that Taiwan is not Chinese. So I think, probably this could be an interesting direction for thinking about how people chose to do or not to do post-Western IR theory. The second issue, is about teaching. Several years ago, I did teaching in Japan for some years. My first institution was more like an international university. I had to teach in English there. After one course, an exchange student from Canada told me that my IR course was the one he felt was closest to his courses back in Canada. I took that as a complement at first but I actually started studying a kind of homegrown IR theorizing and I questioned myself; how come my student picked me on that kind of observation? Again between what I was teaching and what I was researching, because I was teaching Western IR to my students, but I was researching sort of homegrown IR. I think probably I am not the only one, many of us face similar situations that we are using textbooks, which are mostly US centric and it is quite frustrating to teach this to our students and then teach them how to construct those theories. So one future direction for us is to think 
about publishing textbooks that we can use for our own teaching. We don't need to repeat this tiring process of teaching Western IR theory first, then deconstructing them.

Seçkin Köstem (Bilkent University): I think the biggest danger and at the same time the obstacle for homegrown theorizing is to treat IR theory as the top and the best overall. We start from the top, the abstract theoretical level without teaching the students prior steps; "How do you ask questions? What is a research question? How do you make arguments and hypothesis?" In that sense I find Turkish comparativists much more successful. That has got to do with the nature of comparative politics, because in comparative politics you don't have grand theories, realism, liberalism and whatever. People ask research questions and develop theoretical answers to them. When you talk about theorizing in comparative politics, you talk about hypotheses and testing them. Whereas in IR theorizing, you talk about explaining the whole world, which I think is a big obstacle. As far as Turkey is concerned, I think this is a very big obstacle as a faculty member who recently completed his $\mathrm{PhD}$ abroad. And also we should not look down on ourselves. I did my PhD in Canada, and Canadian students faced the same criticism all the time from their professors: "hey it's not original". It is not only people from the developing or non-Western world who are criticized for not being able to theorize, Americans, Canadians face it all the time and I have met many students who had to quit their programs because they were not original enough. Probably, they were better intellectuals than many other students but they could not develop original hypotheses.

I see that Turkish scholars are widely read, their articles are widely downloaded and cited. I have seen many articles written by Turkish scholars that were downloaded more than 3000 times and cited more than 50 times, which is unimaginable for a standard Western academic. I am myself involved in managing a Western academic journal and I know that even professors who teach at top Western universities are downloaded only 300-400 times. Maybe we should shift the focus from grand theorizing to a global level so that we can develop in a healthier manner towards grand theorizing if that is the purpose. To get back to Karen's point, we might also consider ISA as a good platform to get together with people who focus on homegrown theorizing. Again, it is an institution at the core but I can't see any other potential for doing that, if the goal is to bring in everyone from most parts of the world. Eyüp Ersoy (Independent Researcher): There are four points I'd like to talk about. The first and second questions are my favorite questions. Last night we were talking about how come we can eat the best fish in Ankara. Ankara does not have any shores to any sea, but still we eat the best fish in Ankara. The world of IR theory is something like that. There are several countries dealing with civil wars for example, but the best theory for civil wars and its regional implications are written in or produced or developed and consumed in, for example, Boston. How come this has become a pattern is a legitimate thing to ask.

The second point is that there are some troubling patterns of citing in homegrown theorizing. For example, my understanding of manifested ontology is actually inspired by the $12^{\text {th }}$ century Muslim philosopher Suhrawardi, who developed a school of philosophy called Illuminationism. For him, truth manifests itself as reality at different ontological levels. His system of ontological levels, called the Levels of Ontology, was actually the main assumption of Islamic philosophy for centuries. There was also Molla Sadra, a very important philosopher on the relationship between ontology and epistemology. He categorized four relations: there is being by knowledge, being by being, knowledge by being, and knowledge by knowledge. This is his understanding of the relationship between ontology and epistemology. I think 
Moshirzadeh cited him once. My question to the participants here is, should I cite him to be homegrown or not cite him? Or what is it that makes me cite him or not cite him? That is my question.

The third point, the idea that homegrown theory is theorizing in the periphery about the periphery is a self imposed limitation in my view. Scholars in the periphery should be and must be theorizing about the core as well. For example, the most famous peripheral theory is dependency theory, because they also said something about the core and the relationship between the periphery and the core. So we should not limit ourselves to the issues of the periphery; we should be able to tell something about the core and the relationship between the core and periphery.

And my fourth point is related to Dr. Köstem's point. I definitely agree we don't need to theorize paradigms, we don't need to be concerned with grand theories. For example, in the global South or the periphery, there are lots of civil wars. There was a civil war between 1997-2003 in Congo and it is called by some scholars as the world war of Africa, around five million people died. There are of course books and articles about it, but I don't know any theoretical approach from African scholars or from the periphery. We have these experiences that are sometimes very detrimental. We should be able to theorize about them instead of meta-theorizing about homegrown theory.

Knud Erik Jörgensen (Yaşar University): I have five comments. The first is in response to your first question. The thing is that if you look at the development of the discipline, various people asked the very same question some forty or fifty years ago. But theory did not exist as an explicit body of knowledge when it was 'only' a vision of creating a discipline. Before the Second World War people were discussing the issue, namely if there a need for a study of international relations. But after the Second World War a new theme emerged. It was what was discussed in the 1950s and 1960s in the United States and Europe: is there a need for theory? In other words, the aim changed and it became a mission to create a theory of international politics. Given that it was only forty/fifty years ago, people outside the traditional centres of theory production could perhaps learn from how it was dealt with previously, not necessarily copying what was done but at least take some inspiration by looking into how the Europeans and the Americans at the time discussed and created theories. And of course, people also say that there is an advantage of being a latecomer so why not exploit this opportunity.

The second comment concerns the issue of authority and I take the first proper IR journal in German, Zeitschrift für Internationale Beziehungen, as an example. By launching that journal younger German IR scholars managed to revolutionize the discipline in Germany. Because what they did by introducing the double-blind peer review was to undermine the authorities and hierarchies in the field - the gatekeepers. Young professors wanted to do things in new ways. And by introducing peer review - it is a revolution, right? - they took away that authority, that power. And scared of being rejected by unknown people, several old professors didn't dare to submit manuscripts. So it was a two lane street of revolution. The launch of the ZIB is also interesting concerning a second aspect. That is, it was launched by an exchange between Gunther Hellmann and Michael Zürn. Hellmann had a recipe for the future - a way forward - specifically that Germans should adopt US standards. Zürn responded with a telling title, "Sure we can do better - aber muss es auf Amerikanish sein?" Now, the funny thing is that Zürn subsequently adopted 'American' standards whereas Hellmann, as WISC president, promotes Global South perspectives. 
The third comment is about the 'homegrown' issue. Most of us are - I guess - not nomads. So we all come from somewhere, at least most of time. In my own case, that somewhere has been Denmark, London, Italy, Toronto, Barcelona and currently İzmir. It is my experience that I, from these observation posts, look at International Relations somewhat differently. In short, going somewhere might trigger exciting insights and outlooks that would not emerge being somewhere. On the other hand, you do not necessarily need to move yourself, because it is said that Kant never left Königsberg and was still capable of theorizing cosmopolitanism. That's quite an accomplishment, being in a very local Königsberg.

The fourth comment is about the speaker we had previously today from the Buddhistoriented university. When our colleague was not quite sure if there was some Buddhism in the Kyoto School or not, and whether it matters, his comments took me along the avenue of associations. I will therefore remind you of the British diplomat, turned scholar, Michael Nicolson. In a book about him it is highlighted that he looked at the world and international politics through the lenses of the classics. So he had a kind of epistemic reference to the (European) classics. His concepts and dilemmas were developed through the lenses of the classics. Moreover, he pointed out that other people have other epistemic underpinnings, among which some were religious. Take the example of Martin Wight or Morgenthau. People say that you don't know Morgenthau's theory if you do not take into consideration that he was a deeply religious man. Other people have enlightenment philosophers as their prime reference point, and this suggests to me that at least there is a wide range of options to underpin IR theorizing.

The final comment I want to make is that you can have all sort of ideas about how to theorize and from where, how abstract it should be, how local it should be, how homegrown it should be, etc. However, all such ideas have a limited chance of materializing into something close to a collective enterprise if we do not have three things: organization, organization and organization. Without organization, ideas floating around do not necessarily have the intended impact.

Berk Esen (Bilkent University): I think we are almost done. I'll keep my comments short. Now, Seçkin also mentioned a couple of points I wanted to raise. First of all we don't need to be critical and pessimistic about the quality of IR teaching and IR scholarship considering that IR is the field that is almost exclusively composed by scholars born, raised and taught in Western countries using arguments from the system drawing theories from the Western history. Also taking the fact the structural inequalities exist between, for instance, in education between Western and non-Western countries. Also considering that in order to get published and read widely, we need to speak and write English very fluently in a non-Western context is a lot more difficult to do than for those in the Western context.

Also considering how young the discipline is in some of the countries where the speakers are coming from, I think the situation is more positive than negative. What is interesting is that when I look at the countries and universities where the speakers are coming from it is hard to sort of miss this contrast between Western theory being associated with developed countries. Now there are more non-Western thinkers and scholars being associated with some of the rising developing countries or emerging markets, which have now more resources to allocate to their education systems, and which want to pull their weight in the global arena, so there is both an advantage and a disadvantage in that. I completely agree with my neighbor that there is a danger of fragmentation and nationalism with some non-Western 
scholars. I think using this notion of pluralism in their IR theory to sort of promote their own nationalistic perspectives and viewpoints. I guess in answering the first two questions I would say it depends, but probably, yes. The reason why I say it depends is that like Pinar İpek I don't like the post-Western label, but I think we need something that is somewhat different from the Western theory. What we need only so far as certain puzzles are better explained by these theories than what we already have. If they don't necessarily have the same kind of explanatory power, then I am not necessarily that interested in coming up with a non-Western theory. I also don't want the non-Western theories to be sort of turning to an ISA sort of academic model; let's raise the barriers, let's basically keep Western theories out of our universities in the non-Western world and try to come up with our own because we can't compete with the theories coming from the West. I think it is important for us, if we consider ourselves non-Western scholars, to be able contribute to the global debate and engage Western scholars and hopefully do a better job in explaining what is going on in our respected parts of the world. And also, for the second question, we can only do that, come up with theories that explain for instance, with regards to terrorism, if we come up with such a theory and it also explains some terrorist actions happening in other parts of the World, then we can only begin to develop a successful non-Western theory, that would have a wider appeal.

And the other part where I think the periphery can revolutionize IR theory, that goes to the 7th question, is now looking at the mainstream Western theories and paradigms that are been used for close to a century. Now much of it has been built upon Western history completely and modernized, ignoring what happens in the West before Westphalia and certainly what happened in non-Western contexts until the $20^{\text {th }}$ Century/ So the non-Western scholars can easily, over time, revolutionize the IR field by coming up with instances from global history outside of the Western context, using something from Indian history, Chinese history, something from Ottoman, from Latin American history before the arrival of the Spanish or from African history. So I think there are channels and ways of doing that but we need to be vigilant about not falling into this trap of import substitution or completely being closed to the outside world. I guess the other important thing is that in order for this post-Western or homegrown theory to be manufactured we need to have democratic structures within these countries. Unless we have free and open academia in our respected countries it would be difficult to go beyond these kinds of nationalistic notions and really compete with Western academics in explaining what is happening.

Ersel Aydınlı: I would like to thank all of you for the whole workshop and this roundtable, which turned out to be what it was meant to be: we wanted to discuss, discuss, and discuss. Throughout the workshop there have been really valuable not only scholarly products as well as practical suggestions. We are going to write these down and try to categorize them to put in our journal for a larger audience. I would like to thank everybody who came here and but also the people who organized this, our Center's people. I would like to remind everyone that the founders of our Center and journal never tell us what we should do. We have complete academic freedom inside the journal and the Center, and this is how we see fit that we should use our resources and energy. As for All Azimuth, we remain committed to it being a platform for all voices. Thank you. 